\title{
Field evidence on the influence of seagrass landscapes on fish abundance in Bolinao, northern Philippines
}

\author{
J. T. Salita, W. Ekau*, U. Saint-Paul \\ Zentrum für Marine Tropenökologie, Fahrenheitstraße 6, 28359 Bremen, Germany
}

\begin{abstract}
On naturally occurring seagrass patches, 10 plots of $100 \mathrm{~m}^{2}$ each were permanently marked. Seagrasses, macroalgal components and fish assemblages were monitored in February, April and June 1996. Maps of the patch configurations were produced in January 1996 by photographing components and were described in terms of the area of seagrass in a plot (cover), the average size of each seagrass patch, the total number of seagrass patches in a plot, number of halos, shape of a patch (perimeter:area ratio), and complexity of the edges (fractal dimension). Extraction of principal components axes (PCA) on variables describing patch and macrophyte characteristics was employed. Fish numbers from the patchy plots standardized against the fish numbers caught on the corresponding nearby continuous bed showed a positive parabolic relationship against the PCA interpreted as 'continuity of vegetation' for the months of February and June; where curvilinear regressions gave values of $r=0.85$ and 0.94 , respectively. In April, a negative parabola was exhibited against the PCA interpreted as 'macrophyte stands within a patch' $(\mathrm{r}=0.73)$. This trend was basically due to the response of the fishes Siganus fuscescens and Abudefduf sexfasciatus dominating the catch and their preference to intermediate densities of seagrass as the optimal refuge. On the other hand, positive parabolic trends exhibited in February and June imply that fishes tended to prefer plots, which were either extremely patchy or highly continuous, while plots with spatial configurations of average nature were avoided. The differences in fish assemblages and/or seagrass densities within the vegetation for the sampling months explain the different responses. Management implications are discussed.
\end{abstract}

KEY WORDS: Seagrass $\cdot$ Patchiness $\cdot$ Fish $\cdot$ Landscape ecology

Resale or republication not permitted without written consent of the publisher

\section{INTRODUCTION}

The importance of seagrasses in coastal regions, especially in supporting fisheries, has been acknowledged. The seagrass paradigm is that seagrass beds harbor more fish individuals and have higher fish species diversity than the adjacent unvegetated systems. However, in some studies, this may not be the case (see e.g. Hanekom \& Baird 1984, Heck \& Thoman 1984, Ferrell \& Bell 1991, Jenkins et al. 1997). The more common tendencies of fishes to prefer seagrass beds to bare areas led many studies to establish which vegetation attribute harbors higher fish numbers. Thus, habitat complexity or heterogeneity has been evaluated in

*Corresponding author. Email: wekau@zmt.uni-bremen.de seagrass systems as plant surface area per unit area of seafloor (Heck \& Orth 1980), morphology of seagrass species (Martin \& Cooper 1981, Middleton et al. 1984), biomass of seagrass (Stoner 1982), density of seagrass (Bell et al. 1987, Worthington et al. 1992, Horinouchi \& Sano 1999), and density and height of seagrass (Bell \& Westoby 1986b,c). Although habitat heterogeneity brought about by simultaneous occurrence of vegetation and bareness has been considered as a factor influencing fish assemblages (Heck \& Orth 1980, Holt et al. 1983, Middleton et al. 1984, Orth et al. 1984, Bell \& Pollard 1989, MacArthur \& Hyndes 2001) and that such an arrangement is common to observe due to natural causes (e.g. Ogden et al. 1973, Orth 1975, Fonseca 
et al. 1983, Suchanek 1983, Philippart 1994, Heck \& Valentine 1995, Holmquist 1997, Woods \& Schiel 1997, Fonseca \& Bell 1998, Townsend \& Fonseca 1998) and anthropogenic disturbances (e.g. Walker et al. 1989), this has not yet been carefully investigated.

Landscape ecology is concerned with the consequences of spatial patterns on ecological processes (Turner 1989) and provides means in estimating spatial arrangements of habitats and patches (e.g. Li \& Reynolds 1994, 1995, Johnson \& Cage 1997). It also considers the importance of the relativity of scale to the organism under investigation (e.g. Pickett \& Cadenasso 1995). Numerous theoretical approaches and experimental studies in terrestrial ecology show the importance of the properties of landscapes on nutrient flows (Danielson 1991), mating activities (Moller 1988, Tewksbury et al. 1998), foraging behavior (Kareiva 1982, Senft et al. 1987, Rivero-Lynch et al. 1996), competition (Hixon \& Menge 1991), predator-prey interac-

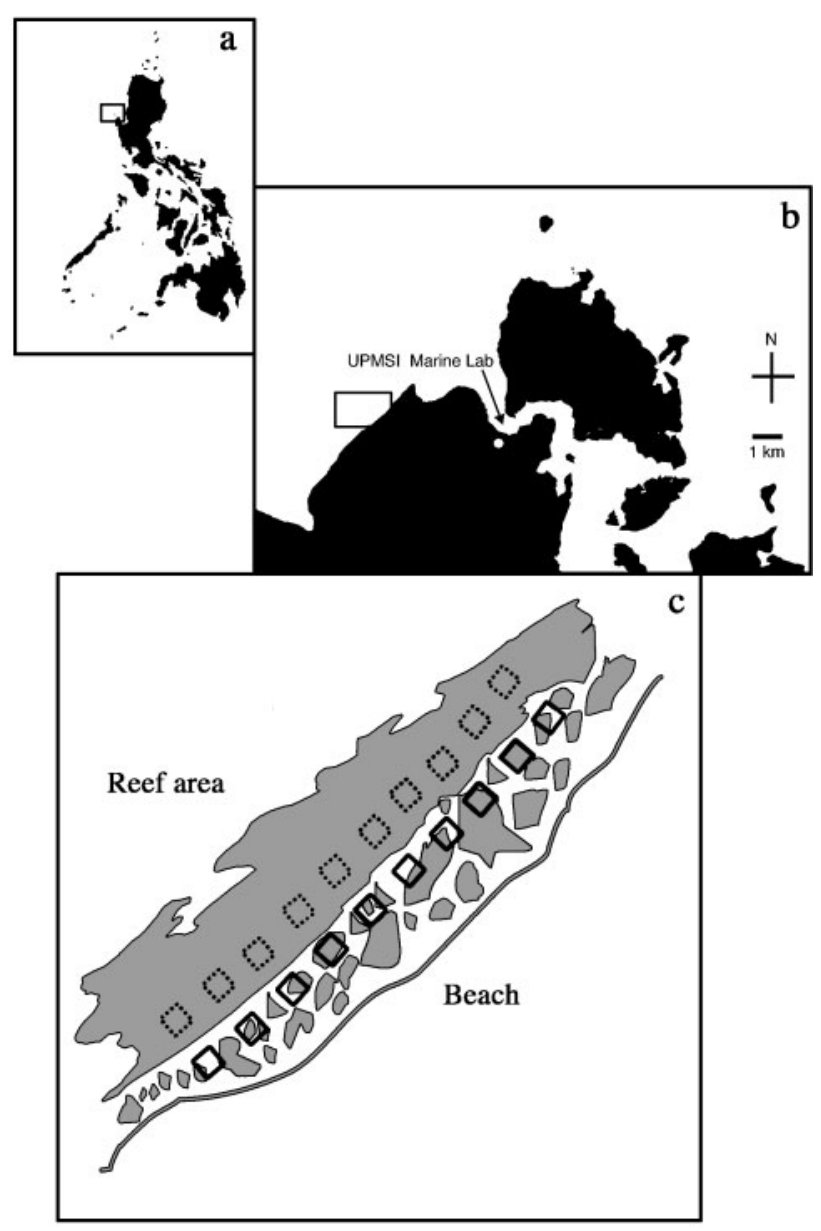

Fig. 1. Map of the study area. (a) Map of the Philippines; (b) Bolinao municipality; (c) approximate positions of the quadrats on the seagrass meadows. Squares with thick lines were permanent quadrats while those with broken lines were temporary tions (Angelstam 1986, Andren \& Angelstam 1988) and recruitment processes (Denno \& Roderick 1990) which, in turn, control faunal abundance and diversity. The decline of populations of American songbirds due to increased predation in fragmented forest landscapes is one of the well-documented examples on how habitat destruction and changing landscape patterns negatively influence bird fauna (e.g. Wilcove 1985, Andren 1992). More advanced topics such as the landscape concept of 'corridors', which connect fragmented landscapes, has been shown by Gilbert et al. (1998) to increase overall faunal abundance (prey microarthropods and its predators) in moss patches. The implication of landscape ecology studies to conservation is, without doubt, immense.

Considering the current rate at which seagrasses are disappearing (Short \& Wyllie-Echeverria 1996), seagrass studies will surely benefit from a landscape ecology perspective. At the same time, seagrass systems are good models for testing the principles of landscape ecology and related or implied topics such as selfsimilarity accross scales and ecological hierarchies (Robbins \& Bell 1994, Virnstein 1995).

A landscape ecology perspective has been taken, considering seagrass patchiness (Irlandi 1994, Irlandi et al. 1995) and the amounts of edges (Bologna \& Heck 1999, Reusch \& Williams 1999), spacing between patches (Bell \& Hicks 1991), seagrass patch size (Bell et al. 1995, Irlandi 1996, 1997, Reusch 1998, Irlandi et al. 1999, Bowden et al. 2001, Hovel \& Lipcius 2001) and seagrass patch shape (Bologna \& Heck 2000) in influencing macroalgal and macroinvertebrate recruitment, growth and survival. Similar works on fish communities are yet to be carried out.

Our study aims to quantify landscape arrangement in naturally occurring seagrass patches and investigate the patterns of fish abundance along these varying spatial configurations and macrophyte structure.

\section{MATERIALS AND METHODS}

Study site. Fieldwork was carried out from December 1995 until June 1996 in Bolinao, Pangasinan, northwestern Philippines, where the University of the Philippines Marine Science Institute (UPMSI) maintains a marine laboratory (Fig. 1). The $24 \mathrm{~km}^{2}$ (fringing) reef flat is dominated by seagrasses (Del Norte \& Pauly 1990). Of the 12 reported seagrass species in the Philippines (Meñez et al. 1983), Fortes (1989) recorded 8 in this area: Enhalus acoroides, Thalassia hemprichii, Cymodocea rotundata, C. serrulata, Syringodium isoetifolium, Halodule uninervis, Halophila ovalis and H. minor. Along Balingasay Beach, a stretch of about $2 \mathrm{~km}$ of seagrass patches was investigated. The dis- 
tance of the nearest coral reef to these patches was approximately $1 \mathrm{~km}$. Between these patches and coral reefs, lies an extensive continuous bed. It was assumed, therefore, that the source of fishes found on the seagrass patches was the nearby continuous meadow.

Ten square plots of $100 \mathrm{~m}^{2}$ area of these patches were permanently marked by steel pegs. Plots were 10 to $15 \mathrm{~m}$ away from each other and were named A to $\mathrm{J}$ throughout the study. Each plot had its own characteristics in terms of the number of patches it enclosed and other inclusive features of these patches (see descriptors of plot characteristics below).

Mapping of the patches. Mapping was carried out by photographing the components: A $35 \mathrm{~mm}$ fix-focus Olympus camera (with an automatic timer mechanism) was attached onto a bamboo stilt of $550 \mathrm{~cm}$ length. About $120 \mathrm{~cm}$ from the bottom of the stilt, a plastic dish was attached and above this dish, a plumb bob was tied. The horizontality of the camera was checked from a height by using a water level. This horizontality was calibrated against the plump bob and a painted point on the dish.

In the field, 2 people operated the stilt. The bamboo was held horizontally by one person and a second person clicked the camera. The camera needed $10 \mathrm{~s}$ before taking a shot and this time was used by the first person to hold up the stilt and balance it, until the plumb bob was directed to the previously determined point on the dish. Using this method, an area of $3.0 \mathrm{~m} \times$ $4.5 \mathrm{~m}$ could be photographed, taking 15 pictures to cover the whole plot. In the laboratory, the developed pictures were pasted together. Photography was carried out during the lowest tides in December 1995 so that the patches were exposed. Seagrass leaves at the edges were flipped into the patches so that the resulting photographs had patch edges free of lying leaves. A $36 \mathrm{~cm}$ levelled reference was always photographed with each component.

Descriptors of plot characteristics. The plot characteristics were described in terms of (1) seagrass cover in the area (\%), (2) the average size of each patch in a plot $\left(\mathrm{m}^{2}\right),(3)$ the number of patches, (4) the average shape of the patches reflected by an average area: perimeter ratio (Wiens et al. 1993), (5) the complexity of the patch edges through fractal dimension, and (6) the total number of halos (holes inside a patch).

The pasted photos of the 10 resulting plots were digitized in the Wacom Tablet. For image processing and computations of seagrass surface area and perimeter, the NIH Image software for the Apple Macintosh was used. Since the plots were $100 \mathrm{~m}^{2}$, the seagrass surface area standardized against $100 \mathrm{~m}^{2}$ should also be equal to the seagrass cover. Fractal dimension was estimated according to the method described in Morse et al. (1985), Lawton (1986) and Williamson \&
Lawton (1991). A series of counts for each plot was repeated 3 to 4 times.

Determination of macrophyte characteristics. On all the seagrass-covered patches of the plots A to J, $0.25 \mathrm{~m}^{2}$ aluminum quadrats with grids of 25 squares were randomly thrown ( $\mathrm{n}=10$ to 30 ). The number of shoots per seagrass species were counted in 5 squares lying diagonally in the quadrat as an estimate of seagrass density. Samples ( $\mathrm{n}=10$ to 100 ) of seagrass species were taken to the laboratory where the number of leaves per shoot were counted and the length and width of the intermediate leaf in each shoot were recorded. Seagrass biomass (above-ground) was computed by using the proportions of seagrass leaf dry weight $(g)$ to seagrass leaf area (leaf length $\times$ leaf width, $\mathrm{cm}^{2}$ ) from Vermaat et al. (1995). Co-occurring macroalgae were also harvested from the 5 small squares of randomly thrown $0.25 \mathrm{~m}^{2}$ aluminum quadrats ( $\mathrm{n}=5$ to 10 ). The algae were cleaned of epiphytes and other entangling organisms by washing them with seawater, dried in the oven at $60^{\circ} \mathrm{C}$ and then weighed to estimate its biomass. These investigations were carried out in February, April and June 1996.

Fishing. All the plots under investigation had only 1 source of fishes, i.e. the nearby continuous bed (see Fig. 1). For this reason, fishes were also collected on the nearby continuous bed (= control plots). Fishes caught from the plots with seagrass patches (= treatment plots) were 'standardized' according to:

$$
\text { Standardized fish catch }(\%)=\frac{T p \times 100}{T p+T c}
$$

where, $\mathrm{Tp}=$ total fish caught in the treatment plot, $\mathrm{Tc}=$ total fish caught in the corresponding control plot.

Each of the control plots also had a $10 \mathrm{~m} \times 10 \mathrm{~m}$ area. However, unlike the treatment plots which were permanent plots, the control plots were randomly chosen at each sampling, always $10 \mathrm{~m}$ away from the treatment plots but approximately oriented in front of the corresponding control plot (Fig. 1). Pegs were constructed a day before actual fishing in order to avoid possible noise disturbance to fishes. Twenty fish collections were made at each time sampling period (see previous section). Due to time constraints, fishing was carried out over 2 to 4 consecutive days, between 10:00 and 14:00 $\mathrm{h}$ during the incoming tide.

Fishing gear and the mechanics of fishing. The fishing gear comprised a square net without top and bottom. Each of the 4 sides of the net were $10 \mathrm{~m}$ in length with a height of $1.5 \mathrm{~m}$. On 1 side, there was an opening and at the opposite side a pocket of about $2 \mathrm{~m}$ length into which fishes were driven and collected. The mesh size of the net was $3 \mathrm{~mm}$ except at the pocket, which had a mesh size of $1 \mathrm{~mm}$. The top of the net had floats at every meter and the bottom had lead weights every $0.5 \mathrm{~m}$. 

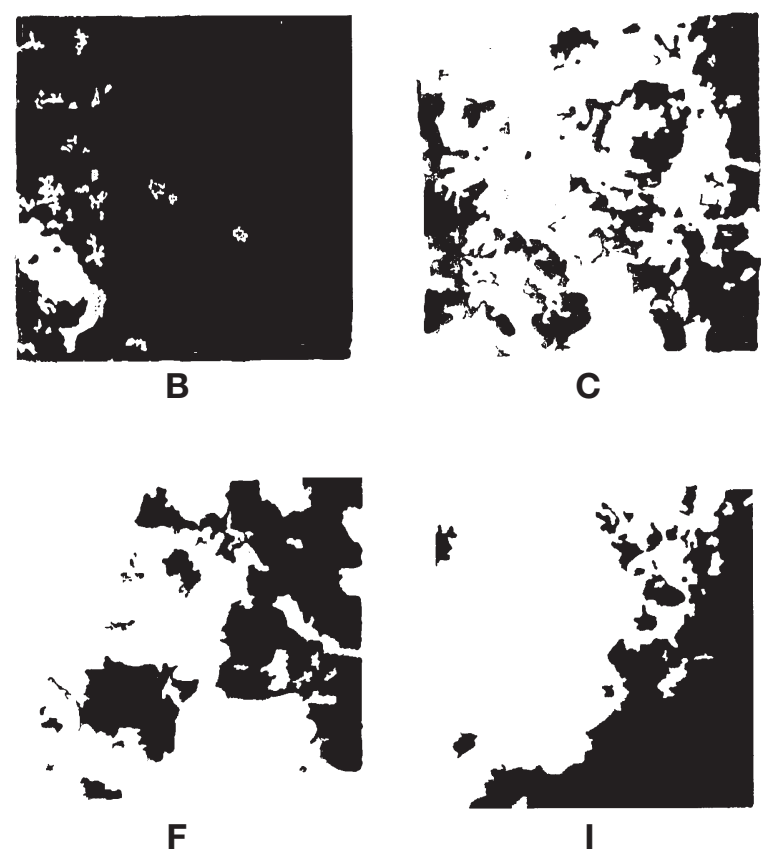

Fig. 2. Sample images of the permanent plots examined. See Table 1 for description of spatial arrangements

The constructed pegs on each plot (whether control or treatment plots) served as the 4 corners of which specially sewn corners of the nets were carefully tied onto the pegs (from the outside of the net) until the 2 ends of the net met, thus forming a square. A few minutes following set up, the net was detached from the peg from 1 corner near the opening. This loose part was then dragged carefully towards the pocket, making sure that the loose part touched the remaining attached net and that the bottom remained on the ground (assured by a diver). When this loose part reached the pocket, the net was pulled so that all the net touched the pocket and that fishes were driven into the pocket. The entire net at the location of the pocket was raised and here fishes were collected, identified and their standard lengths were measured. In this procedure 2 to 3 people carefully carried the net for setting and packing up to avoid disturbance in the neighboring plots.

Statistical analyses. Patterns were generated by extraction of principal components axes (PCA). These axes were used to ordinate the seagrass permanent plots according to their patch descriptors and macrophyte characteristics. PCA extraction was carried out based on a correlation matrix as a means of 'standardizing' the data (Krzanowski 1988). Only PCAs whose eigenvalues were greater than 1.0 were considered and significant component weights were evaluated as $>0.7000$.

The statistic $H$ for the Scheirer-Hare-Ray Extension of the Kruskal-Wallis test (in lieu of cross-factorial ANOVA) was computed after Sokal \& Rohlf (1995).

\section{RESULTS}

The complex spatial patterns in 4 out of 10 plots are portrayed in Fig. 2. This gives the insight that each plot had its own level of heterogeneity and/or complexity, which, in turn is quantified in Table 1. In terms of composition, Plot B had the highest seagrass cover (95\%) and the lowest number of patches (3) while Plot $\mathrm{H}$ had the least seagrass cover $(16 \%)$ although relatively moderate number of patches (21). Plot $\mathrm{C}$ had the highest number of patches (38), the highest average perimeter:area ratio (27.21) and the highest fractal dimension (1.6148). Plot I had the least complex borders (fractal dimension $=1.3184$ ), with the other characteristics being average. In terms of halo presence, Plot $\mathrm{H}$ had the lowest number of halos (3) while Plot A had the most (33).

Three PCA's had eigenvalues more than 1.0 and together contributed to $94 \%$ of the variation in the

Table 1. Characteristics of the 10 photographed plots

\begin{tabular}{|c|c|c|c|c|c|c|}
\hline Plot & $\begin{array}{l}\text { Seagrass } \\
\text { cover }(\%)\end{array}$ & $\begin{array}{l}\text { No. of } \\
\text { patches }\end{array}$ & $\begin{array}{l}\text { Average patch } \\
\text { size }\left(\mathrm{m}^{2}\right)\end{array}$ & $\begin{array}{c}\text { Average } \\
\text { perimeter: area }\end{array}$ & $\begin{array}{c}\text { Fractal } \\
\text { dimension }\end{array}$ & $\begin{array}{l}\text { Total no. } \\
\text { of halos }\end{array}$ \\
\hline A & 65.9 & 15 & 4.39 & 17.73 & 1.5566 & 33 \\
\hline B & 94.6 & 3 & 31.33 & 18.04 & 1.3412 & 25 \\
\hline $\mathrm{C}$ & 38.1 & 38 & 1.00 & 27.21 & 1.6148 & 14 \\
\hline $\mathrm{D}$ & 87.9 & 11 & 7.99 & 1.73 & 1.5178 & 18 \\
\hline E & 55.8 & 20 & 2.79 & 18.16 & 1.5957 & 24 \\
\hline $\mathrm{F}$ & 36.3 & 16 & 2.42 & 23.75 & 1.4305 & 8 \\
\hline $\mathrm{G}$ & 58.6 & 21 & 2.79 & 8.94 & 1.4731 & 7 \\
\hline $\mathrm{H}$ & 16.3 & 21 & 0.78 & 16.04 & 1.3786 & 3 \\
\hline I & 41.6 & 16 & 2.60 & 20.41 & 1.3184 & 8 \\
\hline $\mathrm{J}$ & 79.9 & 6 & 13.33 & 17.98 & 1.4826 & 29 \\
\hline
\end{tabular}


whole matrix (Table 2). The first PCA had a high eigenvalue of 3.06, which already accounted for $51 \%$ of the matrix variation. It was dominated by the weights of seagrass cover, number of patches and average size of each patch. This suggests that the axis could represent the 'general amount of vegetation' in a plot. Seagrass cover and average patch size clearly depict presence of vegetation (high cover and high patch size $=$ more vegetation). However, halo, which is a hole inside a seagrass patch indicates absence of vegetation. Since the number of halos is positively correlated to seagrass cover $(r=0.71)$ and in fact had marginal component weight of 0.700 , there is a disconcordance of interpretation. Interestingly, this suggests that high amounts of seagrass are more prone to halo formation. Halo formation may indicate habitat fragmentation (Fonseca \& Bell 1998). On the other hand, number of patches, which indicates presence of vegetation (more patches $=$ more vegetation), was negatively correlated with seagrass cover. Thus, it appears that patches with higher seagrass cover are less fragmented and vice versa. Whether halo formation may later lead to more patches and therefore fragmentation, is an interesting subject but requires another set of investigations. Thus, the first principal component could not be interpreted solely as amount of vegetation because the associations with the variables dominating this axis follow a 'cause-and-effect' relationship and not because they are somehow similar. The interpretative term 'continuity of vegetation' is more appropriate.

The second PCA, with an eigenvalue of 1.53, was dominated by fractal dimension while the third PCA (eigenvalue $=1.02$ ) by perimeter:area ratio. Thus these last 2 axes represent the morphology of the patches. They were however, not at all correlated $(\mathrm{r}=0.02)$, implying the independent information obtained from each. Since the second PCA contributed a higher percentage in the matrix variation $(25 \%)$ than the third PCA $(17 \%$, whose eigenvalue was also barely over 1.0), the use of the latter in plot ordination was disregarded. This was also done, as trends are easier to see when 2-D representations are constructed, instead of 3. The first and the second PCAs, together already accounted for $77 \%$ of matrix variation, which should be enough to draw some trends.

The seagrass patches were dominated basically by only 2 species, Thalassia hemprichii and Cymodocea rotundata, although at Plots $\mathrm{D}, \mathrm{F}, \mathrm{G}, \mathrm{H}$ and I, minimal stands of Enhalus acoroides and Halodule uninervis occasionally occurred. Table 3 shows the high ranges in macrophyte characteristics of the plots. Seagrass densities varied significantly during the 3 mo of investigation among plots and between species $\left(H_{\text {seagrass species } \times \text { plot } \times \text { month }}=61.315 ; \mathrm{p}<0.001\right)$. The
Table 2. Pertinent information in evaluating principal component (PC) axes extracted from variables describing patch configurations. Highest component weights/factor loadings are in bold

\begin{tabular}{|lccc|}
\hline & PC 1 & PC 2 & PC 3 \\
\hline Eigenvalue & 3.0616 & 1.530199 & 1.024405 \\
\% variation explained & 51.03 & 25.50 & 17.07 \\
Cumulative \% variation & 51.03 & 76.53 & 93.60 \\
explained & & & \\
Component weights: & & & \\
$\quad$ Seagrass cover & $\mathbf{0 . 9 3 2 0}$ & 0.2506 & -0.1192 \\
No. of patches & $\mathbf{- 0 . 8 8 1 4}$ & 0.3264 & 0.0013 \\
Average patch size & $\mathbf{0 . 8 6 2 1}$ & -0.1782 & 0.3238 \\
Perimeter:area ratio & -0.4181 & 0.0672 & $\mathbf{0 . 9 0 1 4}$ \\
Fractal dimension & -0.2038 & $\mathbf{0 . 9 5 7 9}$ & -0.1493 \\
Total number of halos & $\mathbf{0 . 6 7 5 7}$ & 0.6379 & 0.2657 \\
& & & \\
\hline
\end{tabular}

highest (1300) and lowest (380) density values were for plots A and $\mathrm{H}$, respectively, for the month of April. The density values in February and June were more or less on similar ranges (460 to 920 and 540 to 900 , respectively). A third order interaction (seagrass species $\times$ plot $\times$ month) was also highly significant for seagrass lengths $(H=107.29 ; \mathrm{p}<0.001)$. However, seagrass lengths were lowest during February for both species in all plots (by about $50 \%$ ). Macroalgae were dominated by Chaetomorpha crassa. Macroalgal biomasses were very low in February. An extremely high macroalgal biomass was evident in the month of June for Plot A. Significant differences in algal biomass exist due to interaction of plot and month $(H=$ $45.639 ; \mathrm{p}<0.001)$. In terms of the proportion of macroalgal biomass to the overall macrophytic biomass, a range between 9 and $63 \%$ was computed, with most values around $30 \%$. Due to these significant differences in macrophyte characteristics among the sampling months, they had to be treated separately for each month.

Table 4 shows that the first 2 PCAs were usually enough to explain a good proportion $(\approx 75 \%)$ of the matrix variation. For February, the first PCA was substantially dominated by density of seagrasses while the second by leaf length, corresponding to 'horizontal' and 'vertical complexities', respectively, inside the patch. In April, it was the other way around with an addition of macroalgal biomass (having a substantial component weight of -0.7645 ) to the 'horizontal complexity of a patch'. In June, the axes could not be interpreted. At least for the months of February and April, a clear picture of macrophyte complexity within a patch was obtained. Attention is especially drawn for the month of April and a clearer definition of its second axis should be done. The axis, "horizontal macrophytic complexity', which is meant to describe the amount of 
Table 3. Median densities (no. of shoots $\mathrm{m}^{-2}$ ) and leaf lengths $(\mathrm{cm})$ for all seagrass species, seagrass and macroalgal biomasses ( $g$ dry weight $\mathrm{m}^{-2}$ ). Sample size in parentheses

\begin{tabular}{|c|c|c|c|c|c|c|c|}
\hline \multirow{2}{*}{$\begin{array}{c}\text { Month } \\
\text { Plot }\end{array}$} & \multirow{2}{*}{\multicolumn{2}{|c|}{ Density }} & \multicolumn{3}{|c|}{ Seagrasses } & \multirow{2}{*}{\multicolumn{2}{|c|}{$\begin{array}{c}\text { Macroalgae } \\
\text { Biomass }\end{array}$}} \\
\hline & & & Leaf $h$ & height & Biomass & & \\
\hline \multicolumn{8}{|c|}{ February } \\
\hline A & 920.0 & (29) & 9.7 & (21) & 167.72 & 114.8 & (10) \\
\hline B & 770.0 & (30) & 9.0 & (23) & 245.85 & 154.0 & (10) \\
\hline $\mathrm{C}$ & 790.0 & (26) & 7.7 & (22) & 124.02 & 38.9 & $(7)$ \\
\hline $\mathrm{D}$ & 560.0 & (30) & 7.3 & (20) & 95.61 & 153.2 & (9) \\
\hline $\mathrm{E}$ & 600.0 & $(27)$ & 6.7 & (21) & 118.03 & 74.3 & $(7)$ \\
\hline $\mathrm{F}$ & 820.0 & (23) & 8.5 & (22) & 124.57 & 8.7 & (5) \\
\hline G & 520.0 & (25) & 9.1 & (22) & 98.97 & 26.7 & $(7)$ \\
\hline $\mathrm{H}$ & 460.0 & (10) & 8.6 & (22) & 158.72 & 73.7 & $(7)$ \\
\hline I & 750.0 & $(22)$ & 7.7 & (23) & 77.25 & 106.2 & (8) \\
\hline $\mathrm{J}$ & 640.0 & (31) & 9.7 & (23) & 124.16 & 55.2 & $(7)$ \\
\hline \multicolumn{8}{|l|}{ April } \\
\hline A & 1300.0 & (15) & 17.0 & $(200)$ & 646.87 & 47.8 & (10) \\
\hline B & 880.0 & (25) & 13.3 & $(200)$ & 378.60 & 85.0 & (10) \\
\hline $\mathrm{C}$ & 960.0 & (15) & 21.0 & (190) & 489.03 & 75.9 & (10) \\
\hline $\mathrm{D}$ & 700.0 & (15) & 15.1 & (165) & 334.59 & 66.4 & (10) \\
\hline $\mathrm{E}$ & 780.0 & (15) & 19.3 & (198) & 600.40 & 112.7 & (10) \\
\hline $\mathrm{F}$ & 840.0 & (15) & 20.2 & (202) & 425.36 & 116.8 & (10) \\
\hline G & 760.0 & (10) & 15.7 & $(200)$ & 613.85 & 106.7 & (10) \\
\hline $\mathrm{H}$ & 380.0 & (15) & 13.3 & $(200)$ & 215.97 & 54.8 & (10) \\
\hline I & 940.0 & (15) & 22.7 & $(200)$ & 421.17 & 124.6 & (10) \\
\hline $\mathrm{J}$ & 1280.0 & (15) & 20.2 & $(200)$ & 496.80 & 116.9 & (10) \\
\hline \multicolumn{8}{|l|}{ June } \\
\hline A & 540.0 & (25) & 18.0 & $(200)$ & 310.98 & 187.5 & (10) \\
\hline B & 840.0 & (25) & 19.5 & $(200)$ & 370.39 & 127.7 & (10) \\
\hline $\mathrm{C}$ & 760.0 & $(40)$ & 16.4 & $(200)$ & 256.07 & 95.6 & (10) \\
\hline $\mathrm{D}$ & 860.0 & (20) & 17.1 & (200) & 344.62 & 116.7 & (10) \\
\hline $\mathrm{E}$ & 810.0 & (20) & 21.8 & $(200)$ & 541.71 & 112.7 & (10) \\
\hline $\mathrm{F}$ & 900.0 & (15) & 18.4 & $(200)$ & 183.23 & 116.8 & (10) \\
\hline G & 900.0 & (20) & 21.2 & (150) & 561.67 & 106.7 & (10) \\
\hline $\mathrm{H}$ & 700.0 & (15) & 17.2 & (100) & 342.96 & 54.8 & (10) \\
\hline I & 700.0 & (15) & 21.2 & $(200)$ & 336.82 & 124.6 & (10) \\
\hline $\mathrm{J}$ & 600.0 & (25) & 18.6 & (200) & 352.35 & 116.9 & (10) \\
\hline
\end{tabular}

macrophytes comprising the bottom, may be difficult to imagine right away against 'vertical macrophytic complexity', which, in turn, could be readily seen as the contour produced due to differences in leaf heights. Without macroalgal component, 'horizontal macrophytic complexity' is simply the number of seagrass individuals present. The amount of macroalgae is, however, difficult to describe other than expressing it by its weight or biomass. In order to simplify the term 'horizontal macrophytic complexity' and at the same time get away from the scientific accuracy of the word 'density', the term 'macrophyte stands within a patch' is used to mean the amount of macrophytes present (lying or standing) on a given unit of the bottom surface.

Fishes collected were generally dominated by members of the family Labridae (wrasses), especially Halichoeres melanurus as also one of the most frequently occurring species in all of the collection. The parrotfish Scarus sp., and the rabbitfish Siganus fuscescens, were also among the most abundant and most frequently occurring species making the representation of their respective families prominent. The pipefish Syngnathoides biaculeatus, the pufferfish Arothron manilensis, and the flutefish Fistularia commersonii were recorded very often but rarely occurred in groups, so that by number of individuals, they did not dominate. In fewer instances, the cardinal fish Apogon sangiensis, the damsel Abudefduf sexfasciatus, anchovies (Clupeidae) and herrings (Engraulidae) occurred in high numbers. The rest of the collection was recorded in relatively inessential amounts. The total
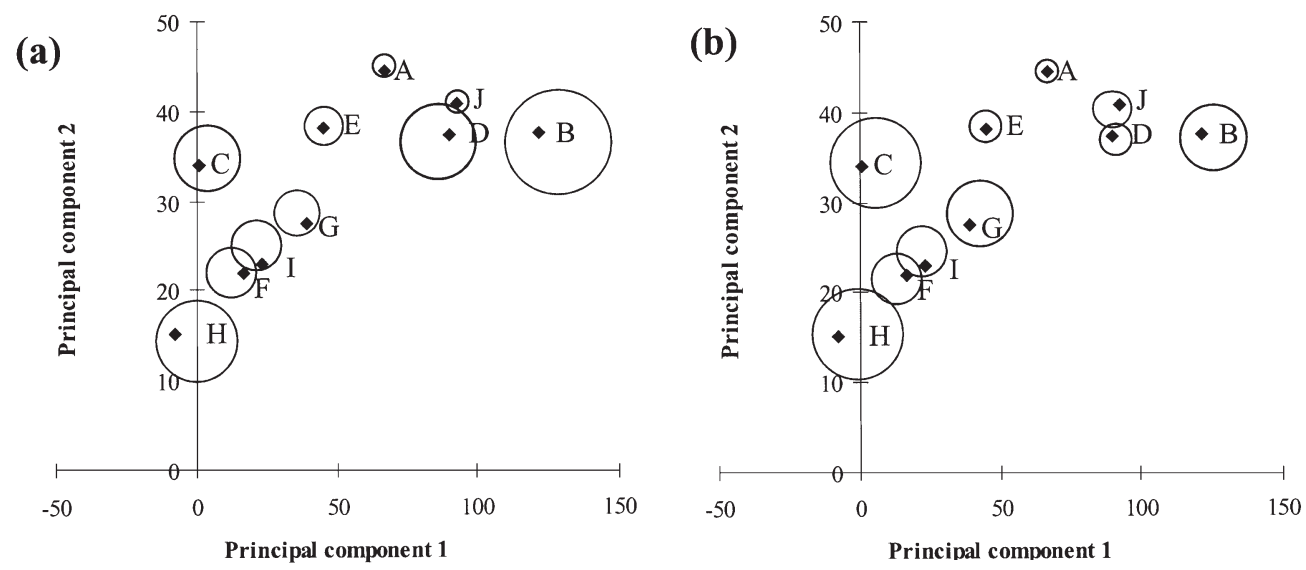

Fig. 3. Ordination of the 10 plots (A to J) based on the principal component axes values in Table 2 . Superimposed circles pertain to the amount of fishes caught (Table 5) for each plot in February (a) and in June (b) 
Table 4. Pertinent information in evaluating principal component (PC) axes extracted from variables pertaining to vegetation characteristics. Highest component weights/factor loadings are presented in bold letters

\begin{tabular}{|lccc|}
\hline & PC 1 & PC 2 & PC 3 \\
\hline February & & & \\
Eigenvalues & 2.8577 & 2.3140 & 1.0628 \\
\% variation explained & 40.83 & 33.06 & 15.18 \\
Cumulative \% variation & 40.83 & 73.89 & 89.07 \\
explained & & & \\
Component weights: & & & \\
Macroalgal biomass & -0.4488 & 0.0426 & $\mathbf{- 0 . 8 2 9 6}$ \\
Length of Thalassia leaves & 0.2317 & $\mathbf{- 0 . 9 0 6 8}$ & -0.1590 \\
Area of Thalassia shoots & 0.6191 & -0.6587 & -0.3724 \\
Density of Thalassia shoots & $\mathbf{- 0 . 8 2 4 2}$ & 0.2412 & -0.3055 \\
Length of Cymodocea leaves & 0.6696 & $\mathbf{0 . 7 0 0 3}$ & -0.1068 \\
Area of Cymodocea shoots & 0.5673 & $\mathbf{0 . 7 1 1 2}$ & -0.2970 \\
Density of Cymodocea shoots & $\mathbf{0 . 8 7 7 4}$ & -0.0416 & -0.1330 \\
April & & & \\
Eigenvalues & 3.3999 & 1.8492 & 1.0029 \\
\% variation explained & 48.57 & 26.42 & 14.33 \\
Cumulative \% variation & 48.57 & 74.99 & 89.31 \\
explained & & & \\
Component weights: & & & \\
Macroalgal biomass & 0.1522 & $\mathbf{- 0 . 7 6 4 5}$ & -0.5591 \\
Length of Thalassia leaves & $\mathbf{- 0 . 9 4 8 6}$ & 0.2157 & 0.1631 \\
Area of Thalassia shoots & $\mathbf{- 0 . 8 4 4 6}$ & 0.3103 & 0.2013 \\
Density of Thalassia shoots & 0.0222 & $\mathbf{- 0 . 7 8 6 0}$ & 0.4507 \\
Length of Cymodocea leaves & $\mathbf{- 0 . 9 1 2 3}$ & -0.1471 & -0.2946 \\
Area of Cymodocea shoots & $\mathbf{- 0 . 8 7 0 3}$ & -0.2219 & -0.3646 \\
Density of Cymodocea shoots & -0.4164 & $\mathbf{- 0 . 6 5 8 6}$ & 0.4475 \\
June & & & \\
Eigenvalues & 3.4241 & 1.8029 & - \\
\% variation explained & 48.92 & 25.76 & \\
Cumulative \% variation & 48.92 & 74.67 & \\
explained & & & \\
Component weights: & & & \\
Variable & & & \\
Macroalgal biomass & -0.1979 & $\mathbf{0 . 8 5 5 9}$ & \\
Length of Thalassia leaves & $\mathbf{0 . 8 5 4 5}$ & -0.2155 & \\
Area of Thalassia shoots & $\mathbf{0 . 9 0 6 4}$ & -0.0114 & \\
Density of Thalassia shoots & $\mathbf{0 . 8 3 7 1}$ & -0.1990 & \\
Length of Cymodocea leaves & 0.5002 & 0.4912 & \\
Area of Cymodocea shoots & 0.4572 & $\mathbf{0 . 8 5 2 3}$ & \\
Density of Cymodocea shoots & $\mathbf{- 0 . 8 2 0 5}$ & 0.1280 & \\
\hline
\end{tabular}

lengths of the fish collected had a high range, between 0.9 and $35.0 \mathrm{~cm}$ but mostly belonged to the size class 2.9 to $3.8 \mathrm{~cm}$. This implies that most of the fishes caught were either juveniles or adults of morphologically small fishes.

Superimposing the values of Table 5 on the plots ordinated along the first 2 PCAs based on patch descriptors reveals a pattern for the months of February and June (Figs. 3 a,b). For both months, the higher catches seemed to be concentrated on the left and right
Table 5. Fish catch (\%) as proportion of the catch in the neighboring continuous plots

\begin{tabular}{|lccr|}
\hline Plot & February & April & June \\
\hline A & 0.0 & 3.3 & 5.3 \\
B & 100.0 & 92.3 & 44.6 \\
C & 40.0 & 92.9 & 81.0 \\
D & 50.0 & 13.6 & 12.5 \\
E & 20.0 & 81.3 & 11.1 \\
F & 33.3 & 50.0 & 33.3 \\
G & 25.0 & 44.4 & 34.1 \\
H & 70.0 & 10.3 & 87.0 \\
I & 33.3 & 99.3 & 33.3 \\
J & 0.0 & 83.3 & 18.2 \\
\hline
\end{tabular}

ends of the ordinated plots. This suggest that fish preferred plots of extreme values, in terms of 'continuity of vegetation', which were Plots $B, C$ and $H$.

In April, a different picture was shown. Fish catch at this month did not respond to the factor 'continuity of vegetation' (Fig. 4a). However, ordinating the plots against the principal component axes corresponding only to macrophyte complexities and superimposing standardized fish catch showed a pattern (Fig. 4b) with a concentration of fish catch at the plots at the middle of the coordinates, which were 'average plots' in terms of the axis, 'macrophyte stands'. Plots $\mathrm{A}$ and $\mathrm{H}$ had depauperate fish numbers and since these plots lie on the extreme values of the 'macrophyte stands' axis, these plots had the densest and the least foliage, respectively.

This probable pattern of nonlinearity was confirmed after performing curvilinear fitting of the second order. Standardized fish catches in February and June, when plotted against the axis, 'continuity of vegetation' gave very good fits of $r=0.84$ and 0.97 , respectively (Fig. 5). The catch in April plotted against 'macrophyte stands within a patch' also gave a significant curvilinear fit of $r=0.73$ (Fig. 6). These show strong confidence for such a behavior occurring in this system.

\section{DISCUSSION}

\section{Quantifying landscape patterns}

Landscape approaches to seagrass systems have been actively applied by Bell \& Hicks (1991), Irlandi (1994, 1996, 1997), Irlandi et al. (1995, 1999), Reusch (1998), Reusch \& Williams (1999), Bologna \& Heck (1999, 2000), Bowden et al. (2001) and Hovel \& Lipcius (2001) showing how invertebrates are influenced by seagrass spatial patterns. Most of these studies involved either the use of artificial seagrasses or when 


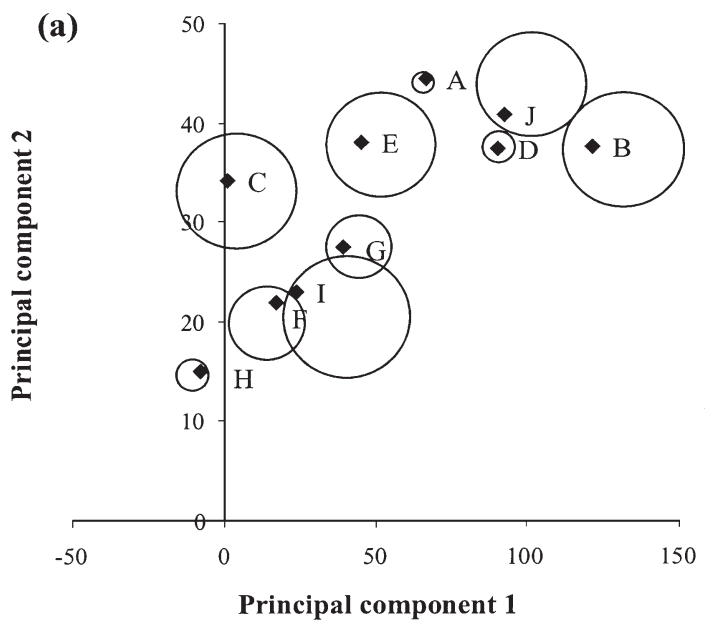

(b)

Principal component 1

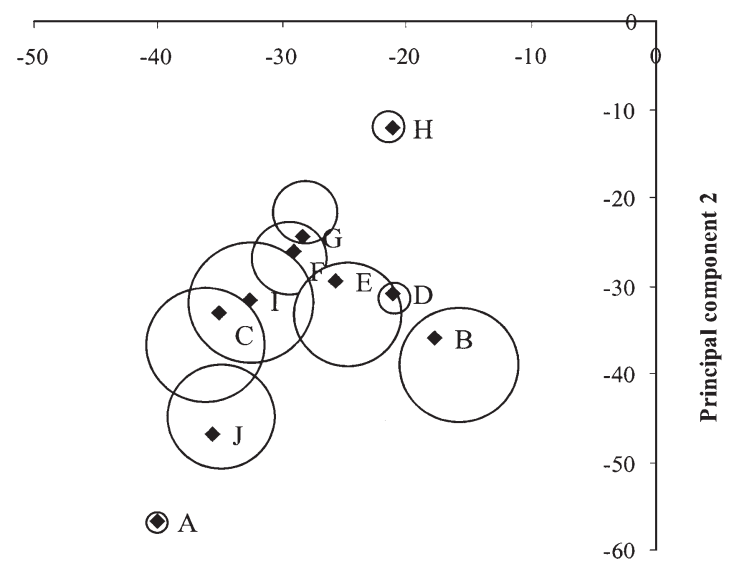

Fig. 4. Patterns of fish catch in April as shown by superimposed circles (Table 5) on plots (A to J) ordinated against the first 2 principal component axes in Table 2 (a) and in Table 4 (b)

done in natural vegetation, seagrasses were either clipped to manipulate spatial patterning, or, seagrass patches were classified to size classes, degree of cover, etc. A quantification of seagrass landscape fragmentation and evaluation of its effects on crab survival was recently done by Hovel \& Lipcius (2001). This is based on aerial photographs, which are cost effective only when carried out in very large scales. Until now the current study is the first attempt to map and quantitatively describe naturally occurring seagrass patches of $100 \mathrm{~m}^{2}$ area by a novel method of photography.

\section{Influence of landscape patterns on fish abundance}

The study shows that landscape patterns influence fish abundance only in terms of continuity of vegeta- tion. Morphology of patches does not seem to affect fish abundance at this scale as shown by the absence of fish abundance patterns against fractal dimension of patches (complexity of edges) and perimeter:area ratio (shape of a patch). An importance of a complex patch form is generally to increase contact zones between 2 media (sensu Frontier 1987). Thus, the positive influences of a stellate seagrass patch compared to a circular patch and higher patch perimeter on settling bivalve larvae were most likely only due to increasing chances of encounters (Bologna \& Heck 2000). Planktonic fishes may show similar tendencies but not the actively swimming fishes in this study. A complex habitat shape is also important as it increases hiding spaces and therefore disallows the accessibility of
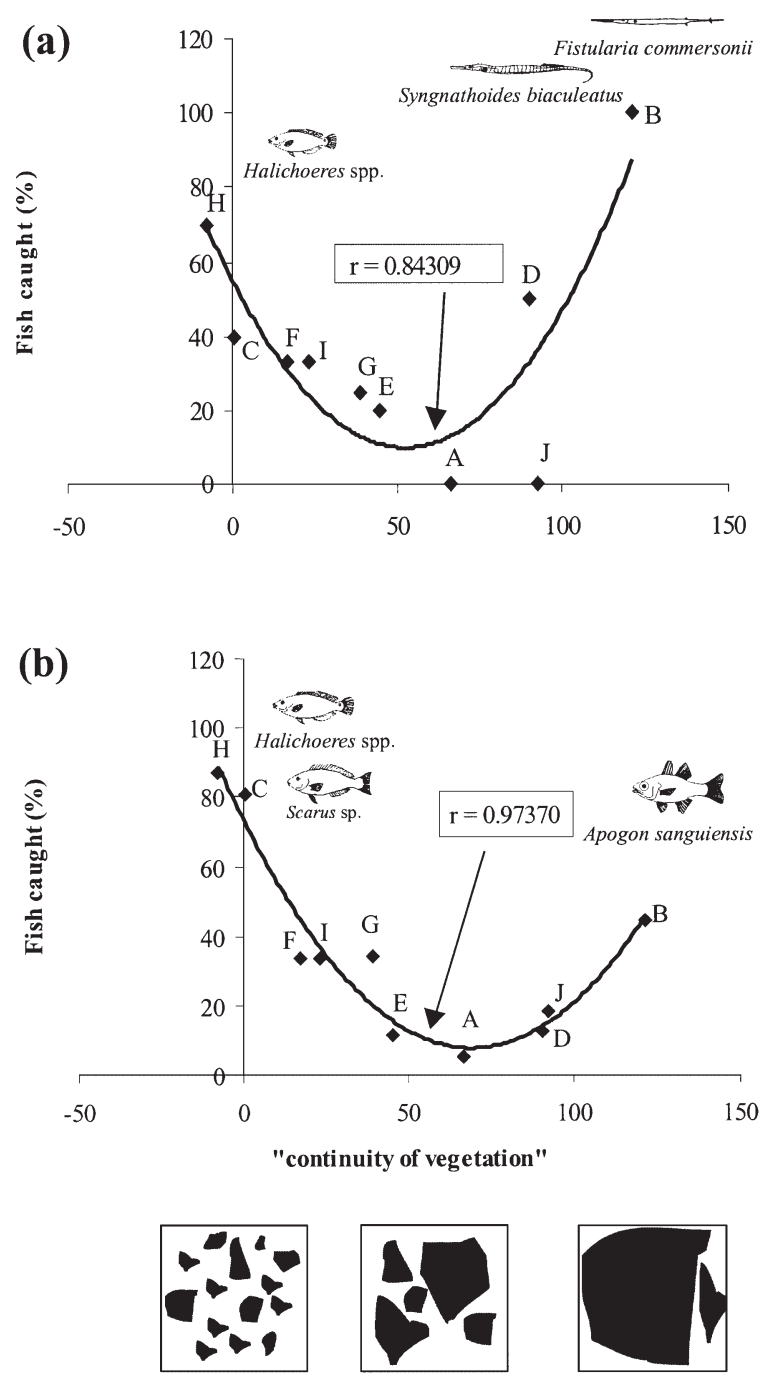

Fig. 5. Response of fish caught from the 10 plots (A to J) on the principal component axis, 'continuity of vegetation', during the months of (a) February and (b) June. Fishes that dominated the extreme plots are also shown 
large predators (Sebens 1991). This cannot be provided by the nonrigid structures of seagrasses for fishes that stay there after their planktonic stage and those that seek temporary refuge in seagrasses. A more common hiding strategy of seagrass fishes is by camouflage (observed e.g. in syngnathids: James \& Heck 1994, Jenkins \& Wheatley 1998). For these reasons, complexities of seagrass patchforms do not signify anything for fishes in this study.

A spatial arrangement with extreme continuities of seagrass vegetation (Fig. 5) harbors high fish abundances, which implies a complete trade-off strategy: either, in highly discontinuous beds, risking predation against facility of obtaining food in the nearby bare areas or, in continuous beds, opting for difficulty of foraging in favor of protection from predators. Complete trade-offs have been documented for some invertebrate species in seagrass meadows (Bologna \& Heck 1999, Boström \& Matilla 1999, Reusch \& Williams 1999) but not in fishes. Sogard \& Olla (1993) experimented on the juvenile walleye pollock's behavior in tanks with artificial seagrasses accounting only for the presence of predators while Connolly (1994) investigated only the importance of presence of food in seagrasses to the juvenile King George whiting. An evaluation of the importance of food and predation risks for fishes in seagrass beds has not been be done. However, Helfman et al. (1997) summarized that trade off decisions in fishes are based on species-specific qualities in terms of the predatory fish's foraging efficiency in particular environments, escape mechanisms as preys, degree of hunger and, sometimes, reproductive state. Further, they stated that fishes put more importance in avoiding predation risks than foraging for food. This means that continuous uninterrupted beds, due to greater provision of protection from predators, should be preferred to patchy beds. A patchy bed gives the immediate impression of high predation risks due to the occurrence of gaps and therefore increased exposure (a measure of assessing predation risk, e.g. Blumstein 1998). As the fishes swim from the continuous bed to the nearby patches (see again Fig. 1), the difference between the 2 types of habitats is already assessed. Encountering gaps upon entering the patches make fishes retreat and attempt to find again the uninterrupted vegetation (the continuous bed nearby). In extremely patchy beds (= low continuity of vegetation, see Fig. 5), the same decision is operational. However, in this situation, the fishes' decision is retarded because of the high accessibility of benthic food. In the actual absence of a predator, the juvenile Theragra chalcogramma does not confine itself in artificial seagrass vegetation (Sogard \& Olla 1993) and if food is abundant outside the seagrass bed, the juvenile Sillaginoides punctata does not go into this habitat (Con-

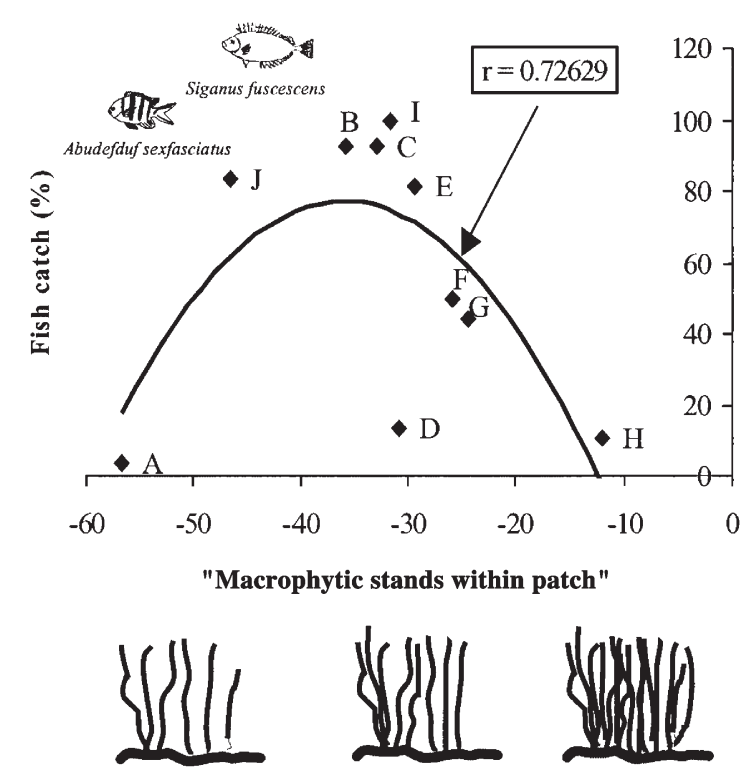

Fig. 6. Response of fish caught in April on the principal component axis, 'macrophytic stands within patch'. Fishes that dominated the intermediate plots are also shown

nolly 1994). Therefore, in the case of the benthic-feeding Halichoeres spp., which dominate the extremely patchy beds, it is probable that the fishes pick up their food on the way back to the continuous bed nearby, and thus spend more time in the extremely patchy beds. If choices were between a continuous bed (e.g. the continuous control plots in this study) and a certain type of patchy bed, an intermediate level of patchiness would always be avoided. An extreme level of patchiness may not necessarily be preferred by fishes but harbors similar numbers of fishes as a continuous bed. This tendency may not necessarily be due to an active choice for a greater amount of food at the expense of predation risks but an impulsive reaction to greater food availability while simultaneously searching for safer refuge.

\section{Differences in response patterns}

The above responses took place only in the sampling months of February and June and not in April and could be due to either or both of 2 reasons. One is that seagrass densities (which roughly estimates 'macrophyte stands within patch' for April, see Table 4) for these months had smaller ranges, i .e. 520 to 920 shoots $\mathrm{m}^{-2}$ in February and 540 to 900 in June while extreme ranges of 380 to 1300 shoots $\mathrm{m}^{-2}$ were recorded in April (see Table 3). Thus, fishes in general may not respond to this independent variable which was more or less similar in February and June. In such conditions, fishes 
seem to opt for a suitable type of habitat in terms of patch characteristics, e.g. continuity of vegetation. This also brings the possibility that vegetation density within patches is more important for fishes than the configuration of the seagrass patches shown as well by Irlandi (1997) for the survival of the clam Mercenaria mercenaria and by Hovel \& Lipcius (2001) for the crab Callinectes sapidus.

Another reason could be that the April sampling was dominated by Siganus fuscescens and Abudefduf sexfasciatus (Fig. 6). S. fuscescens consumes seagrasses and, as small juveniles, high proportions of algal epiphytes (Salita-Espinosa 1991) while A. sexfasciatus feeds on algae and zooplankton (Lieske \& Myers 1994). These fishes clearly perceive the variable 'macrophyte stands within patches' as a barrier from predation more than as its food supply. Salita-Espinosa (1991) estimated that $S$. fuscescens consumes an average of $5 \%$ of seagrass production in this area. This means that even in lower seagrass densities, the high productivity of seagrasses in this area cannot be in limiting supply for these fishes.

In particular, the trend shown in April (Fig. 6) behaves in accordance with the predictions of Heck \& Orth (1980): that increase in fish numbers is positively related to leaf area index (LAI; estimator of amount of canopy) because of increased survival from predation until a certain peak is reached after which conditions become unfavorable, such as anoxia and impediment of movement. Thus, in very dense seagrasses, the abundance of small, presumably prey fishes decreases. Although Bell \& Westoby $(1986 a, b, c)$ and Bell et al. (1987) did not find their results in seagrass beds to agree with the Heck \& Orth model, evidence exists in freshwater systems to support a nonlinear relationship between fishes and macrophytes, i.e. survival of fishes being highest in intermediate macrophyte densities (see reviews of Heck \& Crowder 1991, Orth 1992).

Although the variable 'macrophyte stands' includes seagrass and macroalgae (Table 5), the latter contributed not more than $27 \%$ to the total macrophytic biomass in April. Therefore, this variable is roughly assessed only as seagrass density. Seagrass densities on the plots at which high fish proportions were recorded, about 900 shoots $\mathrm{m}^{-2}$ (see Table 3), were highly favorable for fishes. Gotceitas \& Colgan (1989) computed that the juvenile bluegill sunfishes' threshold level was 576 shoots $\mathrm{m}^{-2}$ in order to escape predation while Gotceitas et al. (1997) predicted this level for the juvenile Atlantic cod utilizing eelgrass to be between 700 to 1000 shoots $\mathrm{m}^{-2}$. For the caught fishes in this month, very low densities such as 400 shoots $\mathrm{m}^{-2}$ may be unfavorable due to increase chances of being foraged on while densities of more than 1200 seagrass shoots $\mathrm{m}^{-2}$ may start to the impede fishes' movement.
Removing the 'unfavorable' seagrass densities and plotting the remaining values against the independent variable, 'continuity of vegetation' did not yield similar trends in February and June. This may be due to fewer data points or simply that herbivorous fishes, on similar conditions (i.e. levels of macrophyte stands), do not reorganize themselves among the different levels of continuity, as they do not need to forage. Seagrass densities were not monitored at the corresponding continuous control plots at any time. It is probable that seagrass densities in these continuous control plots may be extremely different to the corresponding patch-treatment plots. Faced with 'unfavorably' high or low amounts of macrophyte stands on the neighboring continuous plots, fishes may have preferred to stay in a patchy bed.

\section{Conclusions and management implications}

Landscape ecology embraces the issue of patchiness which may be regarded as either positive (= habitat heterogeneity fostering coexistence of species) or negative (= habitat fragmentation). In this study, there is a strong inclination to regard patchiness to be disadvantageous. This is due to the following: Firstly, patchy plots did not always harbor more fishes. Plots with spatial arrangement of intermediate levels were surely avoided while extreme patchy plots harbored fishes not necessarily higher in abundance but similar to plots with high continuity of vegetation. If patchy plots offer much more advantages over continuous beds, all levels of patchiness should harbor more fishes. It is, therefore, risky to say that patchiness per se is positive to fishes, when at 'intermediate' level does not harbor more fishes. On the safe side, a continuous bed should be decided for being positive. Wiens (1985) also warns that although heterogeneity may come into play with patchiness, there remains the operational difficulty of exactly defining and describing patchiness at which organisms indeed perceive it. Secondly, the probable high accessibility of food in extreme patchy plots may lead to fast exploitation of benthic resources by fishes and thus invertebrate faunal impoverishment (e.g. Marquet et al. 1993). Thus, the direction of the scale leading to a solid spatial arrangement should be favored against the other extreme.

This emphasizes the discouragement of activities that may bring about patchiness, especially because anthropogenic disturbances, in general, delay processes that lead to habitat diversity (Caswell \& Cohen 1991). Aside from the obvious related effects of such activities, this study does not compromise the possibility that patchiness may foster increase in fish numbers due to heterogeneity of habitat. However, it must be 
reiterated that equal protection of natural seagrass habitats, whether patchy or continuous, is endorsed. In cases where some habitats have to be given up for developmental purposes, continuous beds should be given priorities for conservation.

The ultimate question in establishing reserves is whether one big area or several small areas of marine habitats should be created. McNeill \& Fairweather (1993) attempted to answer this question using seagrass beds and its fauna. They found contradicting results in their natural and artificial set-ups and discussed the experimental problems and weaknesses of their work. The current study leans on the side of establishing one big seagrass area against several small seagrass areas on the grounds stated above. However, conservation issues involve influence of interactions of several types of habitats with a wide array of faunal assemblages. Thus, care should be taken as the current study specifically dealt with the topic of fishes and their numbers. Themes of diversity and population dynamics were not included. Complications introduced by changes in scale should also be considered. The same goes with applications of the present findings in areas of restoration ecology and seagrass transplantation.

Acknowledgements. This study was part of the first author's dissertation submitted to the University of Bremen and made possible by a scholarship from the German Academic Exchange Service (DAAD). The first author thanks the University of the Philippines Marine Science Institute for providing space during the field work and is deeply grateful to Drs. E. Gomez, G. Jacinto, H. Yap and M. Fortes. The staff of the Institute have all been helpful especially Jack Rengel, Chris Ragos, Chris Diolaso, and Rene Rollon. Al Licuanan gave ideas on photographing components and Ting Nañola on fish gear design. Thomas Mazurkiewicz is acknowledged for the design of the stilt and assistance in the field and data entry and so are the many ZMT students who helped at different stages.

\section{LITERATURE CITED}

Andren H (1992) Corvid density and nest predation in relation to forest fragmentation: a landscape perspective. Ecology 73:794-804

Andren H, Angelstam P (1988) Elevated predation rates as an edge effect in habitat islands: experimental evidence. Ecology 69:544-547

Angelstam P (1986) Predation on ground nesting bird's nests in relation to predator densities and habitat edge. Oikos 47:365-373

Bell JD, Pollard DA (1989) Ecology of fish assemblages and fisheries associated with seagrasses. In: Larkum AWD, McComb AJ, Shepherd SA (eds) Biology of seagrasses: a treatise on the biology of seagrasses with special reference to the Australian region. Elsevier, Amsterdam, p 565-609

Bell JD, Westoby M (1986a) Abundance of macrofauna in dense seagrass is due to habitat preference, not predation. Oecologia 68:205-209

Bell JD, Westoby M (1986b) Importance of local changes in leaf height and density to fish and decapods associated with seagrasses. J Exp Mar Biol Ecol 104:249-274

Bell JD, Westoby M (1986c) Variation in seagrass height and density over a wide spatial scale: effects on common fish and decapods. J Exp Mar Biol Ecol 104:275-295

Bell JD, Westoby M, Steffe AS (1987) Fish larvae settling in seagrass: do they discriminate between beds of different leaf density? J Exp Mar Biol Ecol 111:133-144

Bell SS, Hicks GRF (1991) Marine landscapes and faunal recruitment: a field test with seagrasses and copepods. Mar Ecol Prog Ser 73:61-68

Bell SS, Hall MO, Robbins BD (1995) Toward a landscape approach in seagrass beds: using macroalgal accumulation to address questions of scale. Oecologia 104:163-168

Blumstein DT (1998) Quantifying predation risk for refuging animals: a case study with golden marmots. Ethology 104: 501-516

Bologna PAX, Heck KL Jr (1999) Differential predation and growth rates of bay scallops within a seagrass habitat. J Exp Mar Biol Ecol 239:299-314

Bologna PAX, Heck KL Jr (2000) Impacts of seagrass habitat architecture on bivalve settlement. Estuaries 23:449-457

Boström C, Matilla J (1999) The relative importance of food and shelter for seagrass-associated invertebrates: a latitudinal comparison of habitat choice by isopod grazers. Oecologia 120:162-170

Bowden DA, Rowden AA, Attrill MJ (2001) Effect of patch size and in-patch location on the infaunal macroinvertebrate assemblages of Zostera marina seagrass beds. J Exp Mar Biol Ecol 259:133-154

Caswell H, Cohen JE (1991) Communities in patchy environments: a model of disturbance, competition, and heterogeneity. In: Kolasa J, Pickett STA (eds) Ecological heterogeneity. Ecol Stud 86. Springer-Verlag, New York, p 97-122

Connolly RM (1994) The role of seagrass as preferred habitat for juvenile Sillaginoides punctata (Cuv. \& Val.) (Sillaginidae, Pisces): habitat selection or feeding? J Exp Mar Biol Ecol 180:39-47

Danielson BJ (1991) Communities in a landscape: the influence of habitat heterogeneity of the intereactions between species. Am Nat 138:1105-1120

Del Norte AGC, Pauly D (1990) Virtual population estimates of monthly recruitment and biomass of rabbitfish, Siganus fuscescens off Bolinao, northern Philippines. In: Hirano R, Hanyu I (eds) Proc 2nd Asian Fisheries Forum. Asian Fisheries Society, Manila, p 851-854

Denno RF, Roderick GK (1990) Influence of patch size, vegetation texture, and host plant architecture on the diversity, abundance, and life history styles of sap-feeding herbivores. In: Bell SS, McCoy ED, Mushinsky HR (eds) Habitat structure: the physical arrangement of objects in space. Chapman and Hall, London, p 169-196

Ferrell DJ, Bell JD (1991) Differences among assemblages of fish associated with Zostera capricorni and bare sand over a large spatial scale. Mar Ecol Prog Ser 72:15-24

Fonseca MS, Bell SS (1998) Influence of physical setting on seagrass landscapes near Beaufort, North Carolina, USA. Mar Ecol Prog Ser 171:109-121

Fonseca MS, Zieman JC, Thayer GW, Fisher JS (1983) The role of current velocity in structuring eelgrass (Zostera marina L.) meadows. Estuar Coast Shelf Sci 17:367-380

Fortes MD (1989) Seagrasses: a resource unknown in the ASEAN Region. ICLARM Educ Ser 5, International Center for Living Aquatic Resources Management, Manila 
Frontier S (1987) Applications of fractal theory to ecology. In: Legendre P, Legendre L (eds) Developments in numerical ecology. Springer-Verlag, Berlin, p 335-378

Gilbert F, Gonzales A, Evans-Freke I (1998) Corridors maintain species richness in the fragmented landscapes of a microecosystem. Proc R Soc Lond B 265:577-582

Gotceitas V, Colgan P (1989) Predator foraging success and habitat complexity: quantitative test of the threshold hypothesis. Oecologia 80:158-166

Gotceitas V, Fraser S, Brown JA (1997) Use of eelgrass beds (Zostera marina) by juvenile Atlantic cod (Gadus morhua). Can J Fish Aquat Sci 54:1306-1319

Hanekom N, Baird D (1984) Fish community structures in Zostera and non-Zostera regions of the Kromme estuary, St. Francis Bay. S Afr J Zool 19:295-301

Heck KL Jr, Crowder LB (1991) Habitat structure and predator-prey interactions in vegetated aquatic systems. In: Bell SS, McCoy ED, Mushinsky HR (eds) Habitat structure: the physical arrangement of objects in space. Chapman \& Hall, London, p 281-299

Heck KL Jr, Orth RJ (1980) Seagrass habitats: the roles of habitat complexity, competition and predation in structuring associated fish and motile macroinvertebrate assemblages. In: Kennedy VS (ed) Estuarine perspectives. Academic Press, New York, p 449-464

Heck KL Jr, Thoman TA (1984) The nursery role of seagrass meadows in the upper and lower reaches of the Chesapeake Bay. Estuaries 7:70-92

Heck KL Jr, Valentine JF (1995) Sea urchin herbivory: evidence for long-lasting effects in subtropical seagrass meadows. J Exp Mar Biol Ecol 189:205-217

Helfman GS, Collette BB, Facey DE (1997) The diversity of fishes. Blackwell Science, Boston, MA

Holmquist JG (1997) Disturbance and gap formation in a marine benthic mosaic: influence of shifting macroalgal patches on seagrass structure and mobile invertebrates. Mar Ecol Prog Ser 158:121-130

Holt SA, Kitting CL, Arnold CR (1983) Distribution of young red drums among different sea-grass meadows. Trans Am Fish Soc 112:267-271

Horinouchi M, Sano M (1999) Effects of changes in seagrass shoot density and leaf height on abundances and distribution patterns of juveniles of three gobiid fishes in a Zostera marina bed. Mar Ecol Prog Ser 183:87-94

Hovel KA, Lipcius RN (2001) Habitat fragmentation in a seagrass landscape: patch size and complexity control blue crab survival. Ecology 82:1814-1829

Hixon MA, Menge BA (1991) Species diversity: prey refuges modify the interactive effects of predation and competition. Theor Popul Biol 39:178-200

Irlandi EA (1994) Large- and small-scale effects of habitat structure on rates of predation: how percent coverage of seagrass affects rate of predation and siphon nipping on an infaunal bivalve. Oecologia 98:176-183

Irlandi EA (1996) The effects of seagrass patch size and energy regime on growth of a suspension-feeding bivalve. J Mar Res 54:161-185

Irlandi EA (1997) Seagrass patch size and survivorship of an infaunal bivalve. Oikos 78:511-518

Irlandi EA, Ambrose WG Jr, Orlando BA (1995) Landscape ecology and the marine environment: how spatial configuration of seagrass habitat influences growth and survival of the bay scallop. Oikos 72:307-313

Irlandi EA, Orlando BA, Ambrose WG Jr (1999) Influence of seagrass habitat patch size on growth and survival of juvenile bay scallops, Argopecten irradians concentricus (Say). J Exp Mar Biol Ecol 235:21-43
James PL, Heck KL Jr (1994) The effect of habitat complexity and light intensity on ambush predation within a simulated seagrass habitat. J Exp Mar Biol Ecol 176:187-200

Jenkins GP, Wheatley MJ (1998) The influence of habitat structure on nearshore fish assemblages in a southern Australian embayment: comparison of shallow seagrass, reef algal and unvegetated sand habitats, with emphasis on their importance to recruitment. J Exp Mar Biol Ecol 221:147-172

Jenkins GP, May HMA, Wheatley MJ, Holloway MG (1997) Comparison of fish assemblages associated with seagrass and adjacent unvegetated habitats of Port Phillip Bay and Cornet Inlet, Victoria, Australia, with emphasis on commercial species. Estuar Coast Shelf Sci 44:569-588

Johnson LB, Cage SH (1997) Landscape approaches to the analysis of aquatic ecosystems. Freshw Biol 37:113-132

Kareiva P (1982) Experimental and mathematical analyses of herbivore movement: quantifying the influence of plant spacing and quality on foraging discrimination. Ecol Monogr 52:261-282

Krzanowski WJ (1988) Principles of multivariate analysis. Clarendon Press, Oxford

Lawton JH (1986) Surface availability and insect community structure: the effects of architecture and fractal dimension of plants. In: Juniper BE, Southwood TRE (eds) Insects and plant surfaces. Edward Arnold, London, p 317-331

Li H, Reynolds JF (1994) A simulation experiment to quantify spatial heterogeneity in categorical maps. Ecology 75: 2446-2455

Li H, Reynolds JF (1995) On definition and quantification of heterogeneity. Oikos 73:280-284

Lieske E, Myers R (1994) Coral reef fishes. Harper Collins Publishers, London

Mac Arthur LD, Hyndes GA (2001) Differential use of seagrass assemblages by a suite of odacid species. Estuar Coast Shelf Sci 52:79-90

Marquet PA, Fortin MJ, Pineda J, Wallin DO and 5 others (1993) Ecological and evolutionary consequences of patchiness: a marine-terrestrial perspective. In: Levin SA, Powell TM, Steele JH (eds) Patch dynamics. Lecture Notes Biomath 96. Springer-Verlag, Berlin, p 277-304

Martin FD, Cooper M (1981) A comparison of fish faunas found in pure stands of two tropical Atlantic seagrasses, Thalassia testudinum and Syringodium filiforme. Northeast Gulf Sci 5:31-47

McNeill SE, Fairweather PG (1993) Single large or several small marine reserves? an experimental approach with seagrass fauna. J Biogeogr 20:429-440

Meñez EG, Phillips RC, Calumpong H (1983) Seagrasses from the Philippines. Smithson Contrib Mar Sci 21, Smithsonian Institution, Washington, DC

Middleton MJ, Bell JD, Burchmore JJ, Pollard DA, Pease BC (1984) Structural differences in the fish communities of Zostera capricorni and Posidonia australis seagrass meadows in Botany Bay, New South Wales. Aquat Bot 18: 89-109

Moller AP (1988) Nest predation and nest site choice in passerine birds in habitat patches of different size: a study of magpies and blackbirds. Oikos 53:215-221

Morse DR, Lawton JH, Dodson MM, Williamson MH (1985) Fractal dimension of vegetation and the distribution of arthropod body lengths. Nature 314:731-733

Ogden JC, Brown RA, Salesky N (1973) Grazing by the echinoid Diadema antillarum Phillippi: formation of halos around West Indian patch reefs. Science 182:715-717

Orth RJ (1975) Destruction of eelgrass, Zostera marina, by the cownose ray, Rhinoptera bonasus, in the Chesapeake Bay, Virginia. Chesapeake Sci 16:205-208 
Orth RJ (1992) A perspective on plant-animal interactions in seagrasses: physical and biological determinants influencing plant and animal abundance. In: John DM, Hawkins SJ, Price JH (eds) Plant-animal interactions in the marine benthos. Clarendon Press, Oxford, p 147-164

Orth RJ, Heck KL Jr, van Montfrans J (1984) Faunal communities in seagrass beds: a review of the influence of plant structure and prey characteristics on predator-prey relationships. Estuaries 7:339-350

Philippart CJM (1994) Interactions between Arenicola marina and Zostera noltii on a tidal flat in the Wadden Sea. Mar Ecol Prog Ser 111:251-257

Pickett STA, Cadenasso ML (1995) Landscape ecology: spatial heterogeneity in ecological systems. Science 269:331-334

Reusch TBH (1998) Differing effects of eelgrass Zostera marina on recruitment and growth of associated blue mussels Mytilus edulis. Mar Ecol Prog Ser 167:49-153

Reusch TBH, Williams SL (1999) Macrophyte canopy structure and the success of an invasive marine bivalve. Oikos 84:398-416

Rivero-Lynch AP, Brown VK, Lawton JH (1996) The impact of leaf shape on the feeding preference of insect herbivores: experimental and field studies with Capsella and Phyllotreta. Phil Trans Soc Lon B 351:1671-1677

Robbins BD, Bell SS (1994) Seagrass landscapes a terrestrial approach to the marine subtidal environment. Trends Ecol Evol 9:301-303

Salita-Espinosa JT (1991) Aspects of the feeding biology of juveniles of the white-spotted spinefoot, Siganus fuscescens (Pisces: Siganidae). MS Thesis, University of the Philippines, Quezon City

Sebens KP (1991) Habitat structure and community dynamics in marine benthic systems. In: Bell SS, McCoy ED, Mushinsky HR (eds) Habitat structure: the physical arrangement of objects in space. Chapman \& Hall, London, p 211-234

Senft RL, Coughenour MB, Bailey DW, Rittenhouse LR, Sala OE, Swift DM (1987) Large herbivore foraging and ecological hierarchies. BioScience 37:789-799

Short FT, Wyllie-Echeverria S (1996) Natural and humaninduced disturbances of seagrasses. Environ Conserv 23: $17-27$

Sogard SM, Olla BL (1993) The influence of predator presence on utilization of artificial seagrass habitats by juvenile walleye pollock, Theragra chalcogramma. Environ Biol Fish 37:57-65

Sokal RR, Rohlf FJ (1995) Biometry: the principles and prac-

Editorial responsibility: Otto Kinne (Editor), Oldendorf/Luhe, Germany tice of statistics in biological research, 3rd edn. WH Freeman and Company, New York

Stoner AW (1982) The influence of benthic macrophytes on the foraging behavior of pinfish, Lagodon rhomboides (Linnaeus). J Exp Mar Biol Ecol 58:271-284

Suchanek TH (1983) Control of seagrass communities and sediment distribution by Callianassa (Crustacea: Thalassinidea) bioturbation. J Mar Res 41:281-298

Tewksberry JJ, Heil SJ, Martin TE (1998) Breeding productivity does not decline with increasing fragmentation in a western landscape. Ecology 79:2890-2903

Townsend EC, Fonseca MS (1998) Bioturbation as a potential mechanism influencing spatial heterogeneity of North Carolina seagrass beds. Mar Ecol Prog Ser 169:123-132

Turner MG (1989) Landscape ecology: the effect of pattern on process. Annu Rev Ecol Syst 20:171-197

Vermaat JE, Agawin NSR, Duarte CM, Fortes MD, Marba N, Uri JS (1995) Meadow maintenance, growth and productivity of a mixed Philippine seagrass bed. Mar Ecol Prog Ser 124:215-225

Virnstein RW (1995) Seagrass landscape diversity in the Indian River Lagoon, Florida: the importance of geographic scale and pattern. Bull Mar Sci 57:67-74

Walker DI, Lukatelich RJ, Bastyan G, McComb AJ (1989) Effect of boat moorings on seagrass beds near Perth, Western Australia. Aquat Bot 36:69-77

Wiens JA (1985) Vertebrate responses to environmental patchiness in arid and semiarid ecosystems. In: Pickett STA, White PS (eds) The ecology of natural disturbance and patch dynamics. Academic Press, Orlando, p 169-193

Wiens JA, Stenseth NC, Van Horne B, Ims RA (1993) Ecological mechanisms and landscape ecology. Oikos 66:369-380

Wilcove DS (1985) Nest predation in forest tracts and the decline of migratory songbirds. Ecology 66:1211-1214

Williamson MH, Lawton JH (1991) Fractal geometry of ecological habitats. In: Bell SS, McCoy ED, Mushinsky HR (eds) Habitat structure: the physical arrangement of objects in space. Chapman and Hall, London, p 69-86

Woods CMC, Schiel DR (1997) Use of seagrass Zostera novazelandica (Setchell, 1933) as habitat and food by the crab Macrophthalmus hirtipes (Heller, 1862) (Brachyura: Ocypodidae) on rocky intertidal platforms in southern New Zealand. J Exp Mar Biol Ecol 214:49-65

Worthington DG, Ferrell DJ, McNeill SE, Bell JD (1992) Effects of the shoot density of seagrass on fish and decapods: are correlation evident over larger spatial scales? Mar Biol 112:139-146

Submitted: October 10, 2001; Accepted: August 6, 2002 Proofs received from author(s): January 14, 2003 